\title{
Anonymity 2.0: direct-to-consumer genetic testing and donor conception
}

Citation for published version (APA):

Borry, P., Rusu, O., Dondorp, W., de Wert, G., Knoppers, B. M., \& Howard, H. C. (2014). Anonymity 2.0: direct-to-consumer genetic testing and donor conception. Fertility and Sterility, 101(3), 630-632. https://doi.org/10.1016/j.fertnstert.2013.11.035

Document status and date:

Published: 01/03/2014

DOI:

10.1016/j.fertnstert.2013.11.035

Document Version:

Publisher's PDF, also known as Version of record

Document license:

Taverne

Please check the document version of this publication:

- A submitted manuscript is the version of the article upon submission and before peer-review. There can be important differences between the submitted version and the official published version of record.

People interested in the research are advised to contact the author for the final version of the publication, or visit the DOI to the publisher's website.

- The final author version and the galley proof are versions of the publication after peer review.

- The final published version features the final layout of the paper including the volume, issue and page numbers.

Link to publication

\footnotetext{
General rights rights.

- You may freely distribute the URL identifying the publication in the public portal. please follow below link for the End User Agreement:

www.umlib.nl/taverne-license

Take down policy

If you believe that this document breaches copyright please contact us at:

repository@maastrichtuniversity.nl

providing details and we will investigate your claim.
}

Copyright and moral rights for the publications made accessible in the public portal are retained by the authors and/or other copyright owners and it is a condition of accessing publications that users recognise and abide by the legal requirements associated with these

- Users may download and print one copy of any publication from the public portal for the purpose of private study or research.

- You may not further distribute the material or use it for any profit-making activity or commercial gain

If the publication is distributed under the terms of Article $25 \mathrm{fa}$ of the Dutch Copyright Act, indicated by the "Taverne" license above, 


\section{Anonymity 2.0: direct-to-consumer genetic testing and donor conception}

The offering of genetic and genomic services for genealogical or ancestry purposes is a relatively new development that can undermine the privacy and confidentiality of the participating customers and their relatives (1). Most companies provide lineage-based genetic testing by using mitochondrial DNA or Y chromosome haplotypes. More recently, autosomal markers are also being used to infer ancestry estimations based on genetic variation in various human populations. This approach can also be used to estimate genetic similarity and to make an estimation of the degree of relatedness by comparing the number of markers individuals have in common.

Two specific issues are particularly important in the context of ancestry testing in relation to the subject of donor conception. First, an increasing number of misattributed paternity cases might be discovered. Second, the services provided by these companies might reveal genetically close or more distant relatives that the concerned parties were not aware of. As Family Tree DNA explains about their Family Finder tool, it "provides analysis of your ethnic percentages and connects you with relatives descended from any of your ancestral lines from approximately the most recent five to six generations" (2).

Various Web sites and popular press articles have provided testimonials describing the way DNA testing can lead to the unraveling of family secrets and the tracing of first-degree relatives. These stories also show that a donor and offspring do not necessarily have to use the same service to be identifiable, nor do both of them even have to be tested. Different cases have been described where individuals were able to identify a person to whom they were biologically related. This could be a close relative (e.g., first-degree or second-degree relative), but could also be a more remotely related individual in their pedigree (e.g., third degree or more). The advantage of this service is that it allows individuals to identify last names to which they are biologically connected. Through the so-called nonidentifying information that was provided by the clinic along with DNA testing services, some individuals were in this way able to identify firstdegree relatives (3-5).

It is difficult to estimate how many consumers have been able to find close relatives by using DNA testing, including finding biological parents after an adoption or in the context of donor gamete conception. Hence, although it would appear to be a rare occurrence, the reality is that some people are indeed finding first-degree relatives, including parents, through DNA testing from direct-toconsumer (DTC) genetic testing companies. As a consequence of technological developments, the risk of inadvertently discovering that someone was conceived using gamete donation has increased, as has the risk of identifying the family members of a gamete donor or the gamete donor himself. Furthermore, gamete donors or their family members may also inadvertently or purposefully identify donor-conceived relatives.
Initially, most fertility centers advised parents not to disclose to their children that they were conceived through gamete donation. Policies and views in fertility centers and support groups have evolved, and today they actively support parents in the disclosure of this information to their donorconceived children at an early age. Therefore, although evidence is still limited, there seems to be an increasing intention to disclose and a higher rate of actual disclosure in these families. Irrespective of this continuing debate, the increasing availability of DNA ancestry and genealogical tests adds an additional risk to the accidental disclosure of donor conception. The danger of accidental disclosure is no longer only present from friends or family members who may accidentally or intentionally disclose the donor conception to the donorconceived child, but also from the information stemming from genetic tests that are performed for recreational purposes.

Anonymity in donor-assisted conception has been defended on the grounds that it protects donors and their family members from financial, emotional, or moral obligations toward children conceived with the help of their biologic material. The interests of donors are also being defended on the ground that donors might have monetary or altruistic motivations to donate, but have no intention to engage in a relationship with donor offspring. Some have also argued that abandonment of anonymity might lead to fewer sperm donors.

National regulatory perspectives on the anonymity of gamete donations vary greatly. In countries such as Belgium, Denmark, France, Portugal, and Spain, the anonymity of donors is protected by law. This means that health-care professionals involved in fertility treatments must ensure that they do not provide information about the identity of the donors to the donor recipients or the donor-conceived children. Several other countries such as Austria, the Netherlands, Sweden, Switzerland, and the United Kingdom have changed their legislation in favor of provisions that enable donor-conceived children to request identifying information about their donor when they reach the age of majority (the actual age differing depending on the country). This approach focuses on the right of donor offspring to have access to the identity of their biologic parents.

Calls to move away from donor anonymity have emphasized the importance of openness and transparency. They also represent an increased emphasis on the biologic relatedness of individuals at the expense of the social dimension of relations. The development of DTC genetic testing companies manifests an increasing desire to frame our identity in genetic terms, whether it is in relation to health or in relation to kinship. The DNA tests for ancestry and genealogical purposes challenge the notion of anonymity and genetic privacy. For donor offspring confronted with a situation where health-care professionals are not allowed to provide information about the identity of the donor, a new tool is available that can help them trace their biologic origin. Some might argue that citizens have a legitimate expectation of privacy, and that the use of these services 
by donor-conceived offspring for this purpose would constitute an unreasonable search, thus becoming an infringement of a citizen's constitutional right to privacy. In practice, however, this may not stop these privacy breaches from happening.

Donor-conceived children who were informed about the fact they were conceived through gamete donation often show curiosity about their donor. The exact nature and extent of this curiosity differs between donorconceived children and might range from a desire to get some physical information, biographical information, or a picture or the desire to desiring to meet the donor. The $\mathrm{cu}$ riosity is usually based on a desire to get an image of the donor and identify elements that might be in common with the donor. The information available to donorconceived children is highly dependent on the information provided by the donor, the incentives offered by the fertility clinic for donors to provide information about themselves, and the regulatory requirements with regard to the type of information that may be provided. However, the more information provided by donors, the more points of reference that can be made available to donor-conceived individuals to trace their donors. With expanding Internet resources, it becomes clear that the distinction between nonidentifying and identifying information is becoming increasingly blurred. Once genetic testing enables individuals to infer potential surnames of people to whom they are related, matching this information with the limited nonidentifying biographical information of a donor might drastically reduce the number of individuals who could be the potential donor.

In a context where anonymity is under threat because donor-conceived offspring might be able to trace the donor or vice versa, it becomes more and more important to reflect on the privacy issues related to donor conception. Even in a context that aims to protect anonymity, donors should increasingly reflect on the potential short-term and long-term consequences of their "gift." Although fertility centers can still say that they promise not to disclose identifying information about donors to recipients and donor-conceived offspring, the centers have no control over the tools that might enable the latter individuals to find the identity of donors. They might actively try to look for (information about) their donor by using DNA genetic testing, and donors may do the same to find their offspring. This might be done through the various DTC companies we have discussed, but also through voluntary registries that have been set up with the goal of connecting donor-conceived individuals with donor-conceived siblings as well as locating their donors. This means that through information pamphlets and during intake sessions, fertility clinics should better inform their donors with regard to this issue. As such, potential donors who cannot live with the idea of a potential risk to their privacy may be better off not donating.

Companies selling DTC genetic testing have a responsibility to take the appropriate steps to inform their customers about the privacy risks that are connected to the use of their services. This includes underlining the potential impact of finding information such as nonpaternity or unknown firstdegree biologic relatives. Informed consent forms or service terms of use, however, offer only a limited answer in view of this potentially unwanted information. It must be acknowledged that participation in such an activity potentially constitutes a loss of privacy, one that may not be anticipated by consumers.

Furthermore, health-care professionals working in a context where anonymity is still an option for gamete donors might be confronted with potential breaches of privacy that arise outside the context in which they are able to protect the identity of donors. Well-founded systems to ensure privacy may not prevent potential breaches of privacy realized through the use of relativefinder DNA databases. Acknowledging this reality will become more and more important when recruiting new gamete donors. Hence, it is not only consumers of personal genomics companies that should be made aware of the potential privacy risks, but also those who are considering becoming gamete donors and most certainly potential parents.

Although the number of individuals who have been able to find first-degree relatives by using the services of personal genomics companies is still limited, the development of such services raises questions that need further attention. Recipient couples need to take this additional risk into consideration when deciding whether to disclose a donorassisted conception to their offspring. Donors should be aware of the limits of privacy protection: those who cannot cope with the idea of a potential privacy breach might be better off not donating; and those who decide to donate should be aware that even limited nonidentifying information might become instrumental in identifying them. Fertility clinics have an important responsibility in informing and guiding recipient couples and donors about such privacy risks in the context of donor-assisted conception. They deserve to be properly informed about the level of privacy protection they can expect in the era of personal genome testing.

Pascal Borry, Ph.D. ${ }^{a}$ Olivia Rusu, M.Sc. ${ }^{a}$ Wybo Dondorp, Ph.D. ${ }^{b}$ Guido De Wert, Ph.D. ${ }^{b}$ Bartha Maria Knoppers, Ph.D. ${ }^{c}$ Heidi Carmen Howard, Ph.D. ${ }^{\mathrm{d}, \mathrm{e}}$ ${ }^{a}$ Department of Public Health and Primary Care, KU Leuven, Leuven, Belgium; ${ }^{b}$ Department of Health, Ethics and Society, Research Schools CAPHRI and GROW, Maastricht University, Maastricht, the Netherlands; ${ }^{\mathrm{C}}$ Centre of Genomics and Policy, Faculty of Medicine, Department of Human Genetics, McGill University, Montreal, Quebec, Canada; ${ }^{\mathrm{d}}$ Radboud University Medical Centre Nijmegen, the Netherlands; and ${ }^{\mathrm{e}}$ INSERM, UMR U 1027, Université Toulouse III Paul Sabatier, Département d'Épidémiologie et de Santé Publique, Faculté de Medicine, Toulouse, France

http://dx.doi.org/10.1016/j.fertnstert.2013.11.035 


\section{CONCEPTIONS}

You can discuss this article with its authors and with other ASRM members at http://fertstertforum.com/borryp-anonymity-direct-toconsumer-genetic-testing-donation/

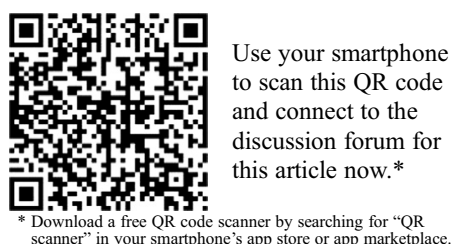

\section{REFERENCES}

1. Borry P, Rusu O, Howard HC. Genetic testing: anonymity of sperm donors under threat. Nature 2013;496:169.

2. Family Tree DNA. Understanding Results: Family Finder. 2013. Available at: http://www.familytreedna.com/faq/answers/default.aspx?fagid=17. Accessed November 22, 2013.

3. 23andme. The 23andme Blog. 2013. Available at: http://blog.23andme $\mathrm{com} /$. Accessed November 22, 2013.

4. Lehmann-Haupt $R$. Are sperm donors really anonymous anymore? Slate, March 1, 2010. Available at: http://www.slate.com/articles/double_x/dou blex/2010/02/are_sperm_donors_really_anonymous_anymore.html. Accessed November 22, 2013.

5. Motluk A. Anonymous sperm donor traced on internet. New Scientist, November 3, 2005. Available at: http://www. newscientist.com/article.ns? $i d=m g 18825244.200$. Accessed November 22, 2013. 